\title{
Excessive Use of Death Penalty as Stoppage Tool for Terrorism: Wrongful Death Executions in Pakistan
}

\author{
Sughra Bibi $^{1} \quad$ Qian Hongdao $^{2} \quad$ Najeeb Ullah $^{3} \quad$ Muhammad Bilawal Khaskheli $^{1}$ \\ Hafiz Abdul Rehman Saleem ${ }^{1}$ \\ 1.PhD Candidates at Guanghua Law School, Zhejiang University, 51 Zhijiang Road, Hangzhou, Zhejiang \\ Province, 310008, China \\ 2.Professor of Law at Guanghua Law School, Zhejiang University, 51 Zhijiang Road, Hangzhou, Zhejiang \\ Province, 310008, China \\ 3.Criminal Lawyer at Peshawar High Court, In Pakistan
}

\begin{abstract}
Wrongful death executions regardless of how infrequent, are a reminder of the fallibility of the justice system and a stain on its well-deserved reputation. The purpose of present study is to highlight the black evil of wrongful death executions in Pakistan while encountering terrorism. The data has been collected from World Justice Project, Pakistan Justice Project, newspapers and human rights reports. After an in-depth analysis of the literature and statistical data, our main findings reveals that incompetent investigation, judicial system, inadequate resources, outdated laws, institutional corruption and unclearly defined Anti-Terrorism Act 1997 lead to high level of wrongful executions under the cover of terrorism in Pakistan. In addition, it transformational reforms are highly recommended in investigation agencies and judiciary at all level for the delivery of justice.
\end{abstract}

Keywords: wrongful convictions; death executions; terrorism; criminal justice system

DOI: $10.7176 / J L P G / 81-05$

\section{Introduction}

Wrongful Convictions and especially wrongful death executions do not only destroy the individuals and their loved ones; it weakens the integrity of the legal system and also public well-being. ${ }^{1}$ In recent years, the Pakistani government has carried out massive executions as a result of an increase in terrorist activity in the country. After a terrorist attack on an army public school that killed more than 130 children on 16 December $2014,{ }^{2}$ the government lifted the informal moratorium on executions that had been in force since $2008 .^{3}$ Although in the first instance, the executions would be limited to those who had been convicted of terrorism-related offenses, detainees were convicted for violations of the common law system were also quickly sent to the gallows. ${ }^{4}$ By the end of 2015, Pakistan had executed 332 people in the first year that the executions were resumed. ${ }^{5}$ In only one year after the moratorium was lifted, executive orders for the mentally ill, physically disabled and juvenile offenders were issued. Since then, more and more cases of unlawful executions have come to light. ${ }^{6}$ In addition, the WJP report indicates that a total of 465 prisoners were executed until May 2017. Among those prisoners are a number of juvenile offenders. ${ }^{7}$

Pakistan is ranked as the fifth productive executioner in the world. ${ }^{8}$ Given the number of convicted prisoners and the speed of executions, the structural shortcomings of Pakistan's criminal justice system pose a significant risk of wrong capital infractions and executions. ${ }^{9}$ As recently concluded in a report: "The criminal justice system of Pakistan is not able to judge capital cases in a just manner". The trends in the death row are a serious tragedy because many innocent people have been hanged, for example Ghulam Qadir, ${ }^{10} \mathrm{Ghulam}$ Sarwar, ${ }^{11}$ Aftab Bahadur ${ }^{12}$ and Shafqat Hussain. ${ }^{1}$ These cases expose the consequences of Pakistan's poor

\footnotetext{
1 Justice Project Pakistan \& Yale Law School, A "Most Serious Crime": Pakistan's Unlawful Use of the Death Penalty, p. 2, www.law.yale.edu/system/files/area/center/schell/2016_09_23_pub_dp_report.pdf, Sep. 2016.

2 Lowenstein, A.K., A “MOST SERIOUS CRIME”: PAKISTAN'S UNLAWFUL USE OF THE DEATH PENALTY. 2016.

${ }^{3}$ BBC News, Pakistan ends death penalty suspension after seven years, www.bbc.com/news/world-asia-31812177, Mar. 10, 2015.

${ }^{4}$ Rohde, S., Choosing Life: Reflections on the Movement to End Capital Punishment. Sw. L. Rev., 2016. 46: p. 219.

${ }^{5}$ Johnson, D.T. and F.E. Zimring, The next frontier: National development, political change, and the death penalty in Asia. 2009: Oxford University Press.

${ }^{6}$ Bencomo, C., The last holdouts: ending the juvenile death penalty in Iran, Saudi Arabia, Sudan, Pakistan, and Yemen. 2008: Human Rights Watch.

${ }^{7}$ Shah, N.A., The Right to a Fair Trial and the Military Justice System in Pakistan. Journal of International Humanitarian Legal Studies, 2016. 7(2): p. 330-362.

${ }^{8} \mathrm{https} / / / \mathrm{www}$. dawn.com/news/1436367 last accessed date, 20.11.2018.

${ }^{9}$ Hood, R. and C. Hoyle, The death penalty: A worldwide perspective. 2015: OUP Oxford.

${ }^{10}$ Richard A. Leo, False Confessions: Causes, Consequences and Implications, pp. 332-343, 37(3) Journal of the American Academy of Psychiatry and the Law, Sep. 2009. Justice Project Pakistan \& Allard K. Lowenstein Intl. Human Rights Clinic, Policing as Torture: A Report

on Systematic Brutality and Torture by the Police in Faisalabad, Pakistan, pp. 23-27,

11 ibid

${ }^{12}$ Justice Project Pakistan, Aftab Bahadur: Internal Case Investigation Memo, Jun. 27, 2012.
} 
criminal justice system and show how these risk factors increase the likelihood that an innocent person will be sentenced to death. ${ }^{2}$

Present study do not advocate the case for abolition of death penalty but the main focus is on wrongful death executions which has been defined as a height of failure of justice system in most fundamental sense, whereby an innocent person has been erroneously convicted ultimately has resulted in long and difficult years of incarceration and subsequent execution.

\section{Conceptual Framework and Literature Review}

In Pakistan, a legislative framework has been designed that aims to combat terrorist activities. This has come with such a broad definition of 'terrorist' that the whole purpose of the laws is swallowed, the Anti-Terrorism Act (ATA) of 1997 is such a piece of legislation ${ }^{3}$. Under the law, processes are carried out urgently, often denying that lawyers behave before the accused time to propose a complete defense. ${ }^{4}$ There is also an increased chance of policing and the fundamental rights of suspects are explicitly suspended. Critical rights that have been essential for Islamic law for centuries have been dissolved. In short, the excessive use and abuse of this law means that parts of suspects whose alleged crimes are not related to terrorism are sentenced to death after extremely unfair trials - while terrorist attacks continue unabated. ${ }^{5}$

Every suspect is entitled to a fair trial in every part of the world as a fundamental human right. ${ }^{6}$ A fair trial is especially important for capital defenders, because an unfair process can lead to the execution of an innocent individual. Trials in Pakistan are plagued with characteristics that are in violation of Article 14 ICCPR and it is estimated that more than $60 \%$ of the people on Pakistan's death row are innocent. ${ }^{7}$

Furthermore, in Pakistan the denial of a fair trial is even clearer in the anti-terrorist banks, where guarantees against the use of forced confessions and evidence obtained through torture and ill-treatment are not applicable. JPP and Reprieve have discovered that many cases that have been tried under this legal regime are not related to common definitions of terrorism. ${ }^{8}$ Pakistan robs life randomly, unlike Article 6 (1) ICCPR, most executions by Pakistan often involve torture, cruel, inhuman, degrading treatment or punishment and or after an unfair trial, contrary to Articles 7 and 14 ICCPR. In these circumstances, the execution constitutes a random deprivation of life. According to the report of the UN rights expert Christ of Heyns "many of the executions carried out by Pakistan" are not in accordance with international standards. " "The Pakistani authorities continue to use the" fight against terrorism "to defend the use of the death penalty. The UN is concerned about "too broad and vague definitions of terrorist crimes"10 ${ }^{10}$ which are a feature of the Pakistani anti-terrorism law of $1997 .{ }^{11}$

Section 6(2) of the ATA lists 18 acts that can fall within the meaning of 'terrorism'. While some of these might well apply to some acts of terrorism, they are generally no more or less than a listing of common crimes (crimes, to be sure, but common crimes):

a. Involves the doing or anything that causes death.

b. Involves grievous violence against a person or grievous body injury or harm to person;

c. Involves grievous damage to property, including government premises, official installations, schools,

${ }^{1}$ Ibid

${ }^{3}$ Ibid

${ }^{4}$ Human Rights Commn. of Pakistan, Slow March to the Gallows: Death Penalty in Pakistan, p. 55

www.fidh.org/IMG/pdf/Pakistan464angconjointpdm.pdf, Jan. 2007.

${ }^{5}$ U.N. Human Rights Committee, General Comment No. 36 on Article 6 of the International Covenant on Civil and Political Rights, on the Right to Life: Revised draft prepared by the Rapporteur, www.ohchr.org/Documents/HRBodies/CCPR/GCArticle6/GCArticle6_EN.pdf, last accessed Nov. 21, 2017. Nigel Rodley \& Matt Pollard, The Death Penalty, The Treatment of Prisoners under International Law, pp. 299300, 3d ed., 2011.

${ }^{6}$ Imtiaz Gul, Terror, Crime and the Tardy Justice System, Express Tribune, www.tribune.com.pk/story/729778/terror-crime-and-thetardyjustice- system/, Jul. 1, 2014. Sabir Shah, Judiciary and Prosecution in India and Pakistan, News Intl., www.thenews.com.pk/TodaysNews-

13-27236-Judiciary-and-prosecution-in-India-and-Pakistan, Dec. 12, 2013.

${ }^{7}$ Please see Pakistan: Alternative Report to the Human Rights Committee July 2016. Ansar Burney Trust, Ansar Burney again urged Pakistan's President and PM to commute death sentences into life http://ansarburney.org/ansar-burney-again-urged-pakistans-president-andpm-to-commute-death-sentences-into-life/ accessed on 4 March 2016

${ }_{8}^{8}$ Please see JPP and Reprieve, Terror on death row: The abuse and overuse of Pakistan's anti-terrorism legislation (December 2014) (Terror on Death Row Report) <http://www.reprieve.org.uk/wp-content/uploads/2014/12/2014_12_18_PUB-Pakistan-Terror-Courts- Report-JPPand-Reprieve.pdf> accessed on 3 March 2016

${ }^{9}$ Please see United Nations, UN rights experts urge Pakistan to halt ongoing surge in executions and to reinstate moratorium on death penalty (29 July 2015)

http://www.ohchr.org/EN/NewsEvents/Pages/DisplayNews.aspx?NewsID=16275\&LangID=E\#sthash.eRwCuSkR accessed on 18 December 2018.

${ }^{10}$ Please See United Nations Human Rights Council, Report of the Special Rapporteur on the independence of judges and lawyers (4 April 2013) (A/HRC/27/23, para 37),. http://daccess-ddsny.

un.org/doc/UNDOC/GEN/G13/126/79/PDF/G1312679.pdf?OpenElement Last accessed on 18 December 2018

${ }^{11}$ Please see ID 9. 
hospitals, offices or any other public or private property including damaging property by ransacking, arson or by any other means;

d. Involves the doing of anything that is likely to cause death or endangers a person's life;

e. Involves kidnapping for ransom, hostage-taking or hijacking;

f. Incites hatred and contempt on religious, sectarian or ethnic basis to stir up violence or cause internal disturbance;

g. Involves taking the law in own hand, award of any punishment by an organization, individual or group whatsoever, not recognized by the law, with a view to coerce, intimidate or terrorize public, individuals, groups, communities, government officials and institutions, including law enforcement agencies beyond the purview of the law of the land;

h. Involves firing on religious congregations, mosques, imambargahs, churches, temples and all other places of worship, or random firing to spread panic, or involves any forcible takeover of mosques or other places of worship;

i. Creates a serious risk to safety of public or a section of the public, or is designed to frighten the general public and thereby prevent them from coming out and carrying on their lawful trade and daily business, and disrupts civil (civic) life;

j. Involves the burning of vehicles or any other serious form of arson;

k. Involves extortion of money (bhatta) or property;

1. Is designed to seriously interfere with or seriously disrupt a communications system or public utility service;

m. Involves serious coercion or intimidation of a public servant in order to force him to discharge or to refrain from discharging his lawful duties;

n. Involves serious violence against a member of the police force, armed forces, civil armed forces, or a public servant;

o. Involves in acts as part of armed resistance by groups or individuals against law enforcement agencies; or

p. Involves in dissemination, preaching ideas, teachings and beliefs as per own interpretation on FM stations or through any other means of communication without explicit approval of the government or its concerned departments. ${ }^{1}$

The government can add this list at any time, without calling on the Parliament. The ATA definition is too broad and vague, and does not offer clear guidelines or administrative policies to prevent arbitrary applications that have contributed to excessive use, abuse and abuse of this legislation. According to Al Jazeera, there are more than 17,000 pending cases under the ATA. ${ }^{2}$ Moreover, the Pakistan justice report 2014 data revealed that 256 of 818 cases of terrorist prosecution do not have a clear connection with terrorism. In these 256 cases, the prisoners were convicted only for charges under the Pakistani criminal code; despite the fact that the cases were tried in the anti-terrorist court, the link with terrorism was not proven. ${ }^{3}$

Zafar Iqbal execution under the Anti-Terrorism Act 1997 is one of the case studies of unlawful executions by Pakistan. Zafar was arrested in April 2003 after the death of his father by the motive that he had murdered his father for a running disagreement over land. Zafar had no ties with terrorism or a terrorist organization, but he was sentenced to death according to the Pakistani Anti-Terrorism Act 1997. ${ }^{4}$ During the trial, Zafar consistently maintained his innocence. However, Zafar's unlawful condemnation and death penalty under the Anti-Terrorism Act 1997 (ATA) meant that he was in prison under the ATA. He was executed on March 17, 2015. Some other cases such as Shafaqat Hussian ${ }^{5}$ 14-year-old (discussed below), ${ }^{6}$ Muhammad Akhtar ${ }^{1}$ and Muhammad Amin ${ }^{2}$

\footnotetext{
${ }^{1}$ Constitution of the Islamic Republic of Pakistan, supra n. 52, at art. 14(2). Asian Human Rights Commn., AHRC Special Report: Torture Situation in Pakistan, pp. 1-2, www.humanrights.asia/resources/special-reports/AHRC-SPR-001-2010-01/, Jun. 26, 2010.

2 Al Jazeera, 'Pakistan activists upset by new security law', 13 July 2014 ; available at: http://www.aljazeera.com/indepth/features/2014/07/pakistan-activists-upsetnew-security-law-201471316625972647.html (last accessed 18 December 2018)

${ }^{3}$ Justice Project Pakistan \& Allard K. Lowenstein Intl. Human Rights Clinic, Policing as Torture: A Report on Systematic Brutality and Torture by the Police in Faisalabad, Pakistan, https://law.yale.edu/system/files/documents/pdf/JPP Launch Report 050514.pdf, pp. 23-27, May 2014. Police were documented as having "beaten victims, suspended, stretched and crushed them, forced them to witness other people's torture, put them in solitary confinement, subjected them to sleep and sensory deprivation, confined them to small spaces, exposed them to extreme temperatures, humiliated them by imposing culturally inappropriate or unpleasant circumstances, and sexually abused them." Ibid. at p. 5 .

${ }^{5}$ U.N. Commn. On Human Rights, Report of the Special Rapporteur on torture and cruel, inhuman or degrading treatment or punishment, Visit by the Special Rapporteur to Pakistan, U.N. Doc. E/CN.4/1997/7/Add.2, 1996.

${ }^{6}$ Please see Terror on death row, the abuse and overuse of Pakistan's anti-terrorism legislation. A report by Justice Project Pakistan and Reprieve, December 2014. Website https://reprieve.org.uk/wp-content/uploads/2014/12/2014_12_18_PUB-Pakistan-Terror-Courts-ReportJPP-and-Reprieve.pdf last accessed December 19, 2018.
} 
(youthful) were all sentenced to death under the Anti-Terrorism Act and have been unjustly hanged, and in all these cases, police torture and brutality ${ }^{3}$ have been reported for obtaining false confessions.

The wrongful execution under the cover of terrorism is not only the tragedy of Pakistan, but it is also practiced in other parts of the world. In the Islamic Republic of Iran, the 1991 Islamic Penal Code, as amended in 2013, provides for the death penalty for moharebeh or "enmity against God", which corresponds to an armed insurrection aiming to sow panic among the population ${ }^{4}$. People who have not committed violent acts and who come from ethnic or religious minorities have, however, been executed for moharebeh. For example, in 2015 there were alleged executions for this crime against Sunnis and a Kurd, because of alleged cooperation with the party for a free life in Kurdistan ${ }^{5}$ (PJAK). ${ }^{6}$

On $2^{\text {nd }}$ January, 2016, 47 men were executed at the same time in 12 Saudi cities, in the name of a hadd (that is, a crime that is believed to have been committed against God and where the sentence is always death). ${ }^{7}$ While 43 of them were convicted of their involvement in various Al-Qaeda attacks, the remaining four, all Shiites, were sentenced for demanding political reforms by demonstrating in 2011 the majority of Shiite Eastern Province. ${ }^{8}$

In 2012, the journalists and members of the opposition in Ethiopia were sentenced according to the AntiTerrorism Proclamation 2009 for "criticizing the government, demanding reforms and discussing demonstrations and arrests". ${ }^{9}$ In 2016, Algeria issued 62 death sentences for terrorist acts, in many cases after a trial in absentia. ${ }^{10}$

\section{The Big Picture}

\subsection{Current Situation of Death Sentences in Pakistan}

Pakistan applies the mandatory death penalty for a range of offenses including murder, terrorism-related offenses resulting in death, and adultery. ${ }^{11}$ At the court's discretion, the death penalty may also be imposed for drug trafficking, apostasy, rape, kidnapping, treason, and military offenses. ${ }^{12}$ Hanging is the sole method of execution. Although religious law may authorize other methods of execution, none is applied in practice. ${ }^{13}$

\section{Death Row Trends in Pakistan}

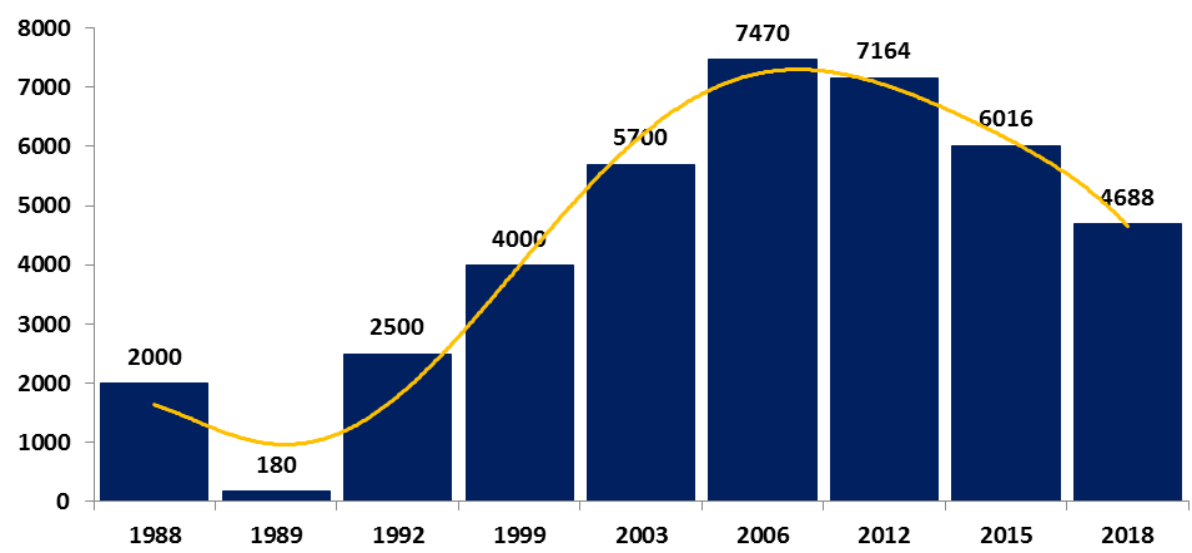

Figure 1: Death Row Trends in Pakistan (Author generated: Data source Dawn.com 5 Oct, 2018 and JPP 2016)

\footnotetext{
${ }^{1}$ Ibid.

${ }^{2}$ Ibid.

${ }^{3}$ Justice Project Pakistan and Allard K. Lowenstein International Human Rights Clinic, Yale Law School, 'Policing as torture: A report on systematic brutality and torture by the police in Faisalabad, Pakistan', March 2014, p. ii; available at: http://www.law.yale.edu/documents/pdf/JPP_Launch_Report_050514.pdf last accessed 18 December 2018.

4 Please see Death Penalty Worldwide, Death Penalty Database, Iran, Crimes and Offenders Punishable by Death. Website https://www.deathpenaltyworldwide.org/country-search-post.cfm?country=Iran\#f10-3 last accessed 17 December 2018.

${ }_{6}^{5}$ A political organization that was declared illegal in Iran.

6 Please see Amnesty International, Global Report, Death Sentences and Executions - 2015 , 2016 https://www.amnesty.org/download/Documents/ACT5034872016ENGLISH.PDF last accessed December 18, 2018.

${ }^{7}$ Please see Human Rights Watch, Saudi Arabia: Mass Execution Largest Since 1980, 4 January 2016

${ }^{8}$ Please see Amnesty International, Shia cleric among 47 executed by Saudi Arabia in a single day, 2 January 2016

${ }^{9}$ Ibid.

${ }^{10}$ Shah, N.A., The Right to a Fair Trial and the Military Justice System in Pakistan. Journal of International Humanitarian Legal Studies, 2016. 7(2): p. 330-362.

${ }^{11}$ Shah, N.A., The Right to a Fair Trial and the Military Justice System in Pakistan. Journal of International Humanitarian Legal Studies, 2016. 7(2): p. 330-362.

${ }^{12}$ Cautain, J.-F., Standing against death penalty. 2017.

${ }^{13}$ Hood, R. and C. Hoyle, The death penalty: A worldwide perspective. 2015: OUP Oxford.
} 
Researcher has reported 8200 prisoners on death row in Pakistan till 2018 ; $^{1}$ in addition Figure 1 shows the death row trends in Pakistan from 1988 to 2018. The trend shows a mounting increase in death row sentence after 1989 and accelerated with a high face from 1999 due to the increase in the terrorist's attacks. Furthermore, the trends show that between 2012 and 2018, death row population decrease from 7470 to 4688 - a surprising one third reduction.

According to JJP, the Supreme Court of Pakistan reversed $85 \%$ of the death sentences on the basis of erroneous, incomplete and fabricated evidence and led research into acquittal or reduction of the judgments. Since 2014, the court of the Supreme Court has heard 546 cases and acquitted the death penalty of 467 persons. As stated in the introduction, the death sentence in Pakistan is used as a political instrument that weakens the rule of law ${ }^{2}$. According to the findings of World Justice Project (WJP) research 2017 and WJP Pakistan Justice Sector Survey 2017, it is clear that institutional corruption, bribery, outdated laws, incompetent criminal investigations are the main causes of unlawful death sentences or other unlawful convictions in Pakistan. ${ }^{3}$

\subsection{Institutional involvement in Corruption}

The Transparency international research team has found a high correlation between corruption and terrorism in conflict-affected countries. ${ }^{4}$ In every country where widespread corruption has made the country or neighboring countries vulnerable to terrorist activities, terrorist organizations are ready to use it to finance and carry out their deeds.

According to the common person perception about the justice system of Pakistan is negative and the perception about government personnel ${ }^{5}$ and institution in the corruption are high as indicated in Figure 2, the statistic for police are higher than the rest of the other institutions.

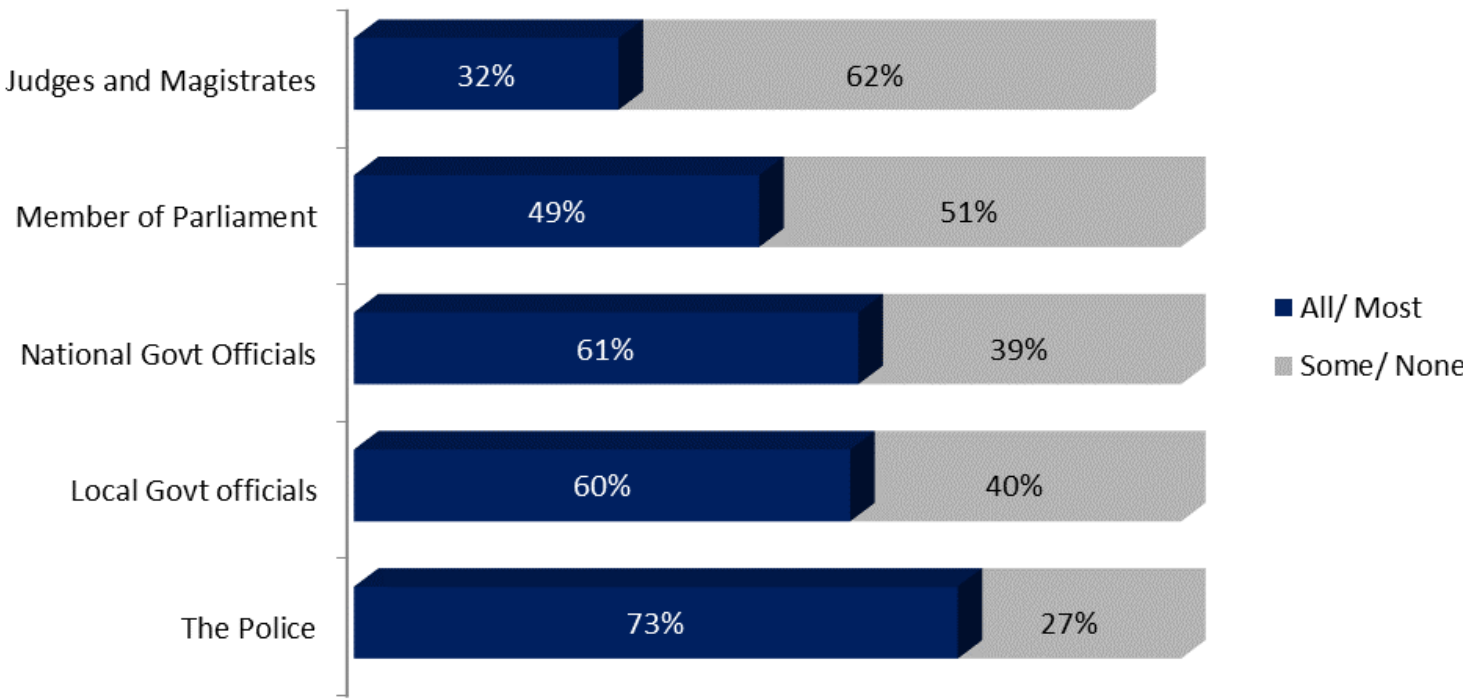

Figure 2: Perception about Corruption Involvement 2017 (Author generated: Source WJP Pakistan Project 2017)

Common person in Pakistan believe that the government official are highly involved in the corrupt practices. According to Figure 2, police are viewed as the most involved institution in corruption, $73 \%$ of the people think that all the policemen are involved while $27 \%$ have the opinion the some are involved. In addition the perception about local/national government officials and legislators are not good. Furthermore judges are perceived to be least involved in the corrupt practices. The WJP Pakistan report 2017 and other source such as new papers (Dawn news) and TV channels (BBC, ARY) reported that high corruption in the police department in Pakistan highly leads to wrongful convictions in the country. ${ }^{6}$ Aftab Bahadur ${ }^{7}$ is an open shut case of police in

\footnotetext{
${ }^{1}$ Johnson, D.T. and F.E. Zimring, The next frontier: National development, political change, and the death penalty in Asia. 2009: Oxford University Press.

${ }^{2}$ Pakes, F. (2017). Comparative criminal justice. Routledge.

${ }^{3}$ Reckless, W. C. (2017). The use of the death penalty: a factual statement. In Capital Punishment (pp. 38-62). Routledge.

${ }^{4}$ See Shelley, D. L. (2018). Terrorism and International Crime -Corruption as the Enabler (pp. 1-5).

${ }^{5}$ Kemal, A. R. (2003). Institutional change, growth, and poverty levels in Pakistan. The Pakistan Development Review, 42(4), 299-311.

${ }^{6} \mathrm{https}: / /$ www.dawn.com/news/1343720 Retrieved, 12 December, 2018.

${ }^{7}$ Please see Clive Stafford Smith (2015), Aftab Bahadur's killing is not only tragic, it is perverse. The Guardian 10 Jun, 2015 , website: https://www.theguardian.com/commentisfree/2015/jun/10/aftab-bahadur-death-tragic-perverse-pakistan . Also see My 22 years on Pakistan's death row could end this week. What purpose will my execution serve? The Guardian 10 Jun, 2015.
} 
human torture and forced confession. According to "The Guardian" newspaper, when he was arrested, the police asked for a 50,000-rupees as bribe and said they would let him go if he paid. But Aftab was a poor plumber's apprentice and he could not pay. Aftab was convicted under the Speedy Trials Act in April 1993, this act was intended for terrorists - and was executed in 2015 for a crime he never committed.

\subsection{Criminal Investigation and Justice System}

Corruption is considered one of the leading factors of wrongful conviction in Pakistan, but there are many other issues faced by the criminal investigation and justice system in the country. When it comes to criminal courts, inadequate resources were cited as their most serious problem ${ }^{1}$. In Figure 3 , and 4 represent, the criminal investigative services and justice system average responses from Pakistani criminal experts surveyed for the WJP Rule of Law Index 2017-2018. Perceptions data are rated on a scale of 1-10, where 1 is not serious and 10 very serious. Furthermore, Figure 3; list the incompetence's of investigation services (police) i.e. lack of proactive investigation methods, deficient evidence collection mechanism, inadequate resources, corrupt and incompetent investigators, corrupt prosecutors and inadequate witness protection. WJP report cited incompetence of criminal investigator as the most serious issue facing by investigative services in Pakistan. On the other hand when it comes to the problem facing by criminal justice system, the most cited issues are inadequate resources, poor judicial decisions and inadequate alternative dispute resolution methods ${ }^{2}$ as shown in Figure 4.

\section{Problems faced by investigative services}

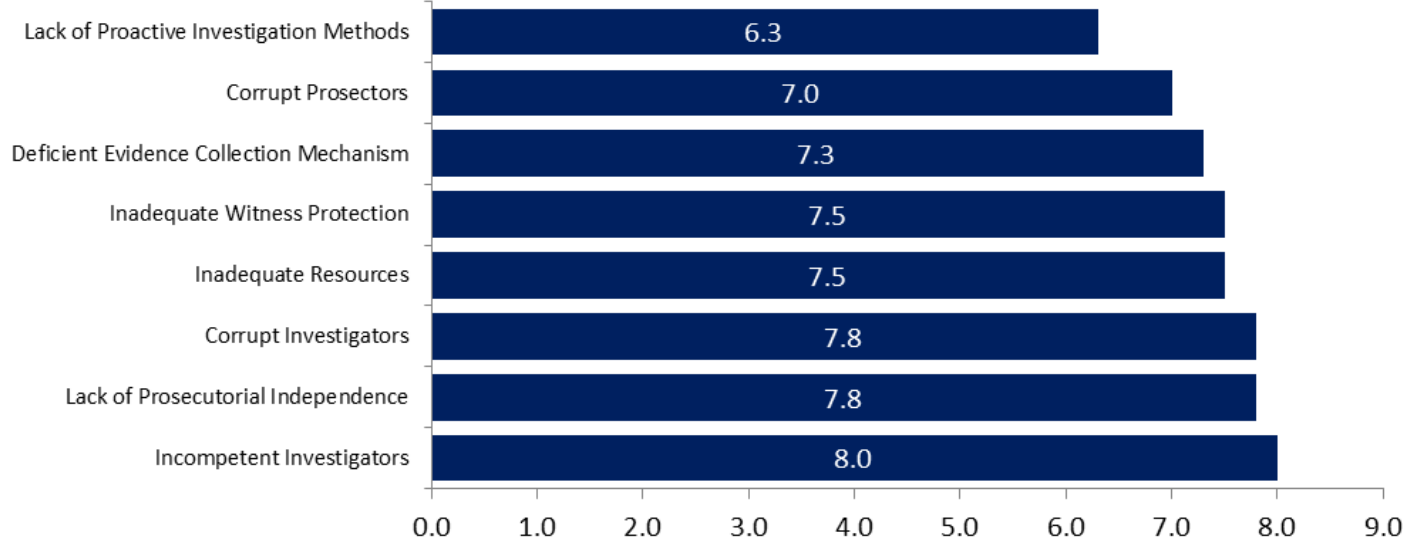

Figure 3: Problem faced by Investigative Service and Criminal Courts (Author generated; Data Source: WJP Rule of Law Index 2017-2018)

Overall most of the issues faced by criminal investigation services are rated above the 7 point on average and problems faced by criminal justice system are rated above 6.5 on average. All the mentioned deficiencies in the criminal investigation and justice system collectively leads to the wrongful conviction of innocent persons, which is also clear from the high death sentence rate in Pakistan as shown in Figure 1. The Supreme Court of Pakistan has acquitted or relax reduce the death sentence of 467 person ( $85 \%$ of total) out of 546 cases, which has provides evidence regarding the failure of investigative services and the incompetence of lower courts. ${ }^{3}$

\footnotetext{
${ }^{1}$ Staser McGill, A. K., \& Gray, D. H. (2012). Challenges to International Counterterrorism Intelligence Sharing. Global Security Studies, 3(3)

2 https://worldjusticeproject.org/ Retrieved, December 22, 2018.

${ }^{3}$ Ibid
} 
IIII

||S|E

\section{Problems Faced by Criminal Courts}

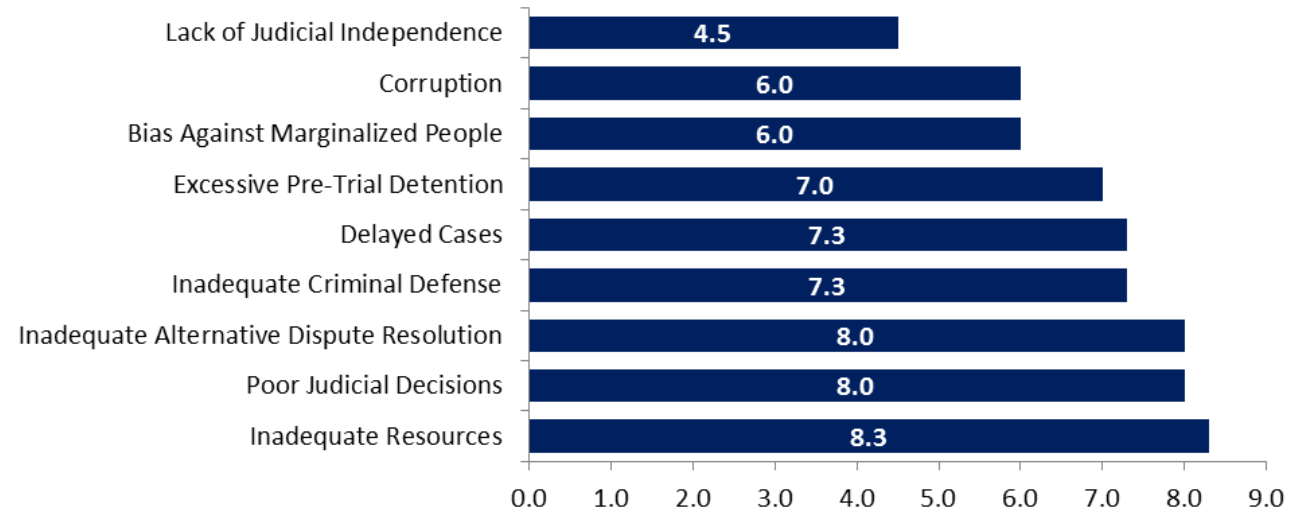

Figure 4: Problem faced by Investigative Service and Criminal Courts (Author generated; Data Source: WJP Rule of Law Index 2017-2018)

\subsection{Unlawful use of the death penalty}

According to Justice Project Pakistan 2016, entitled, "a "most serious crime": Pakistan's unlawful use of the death penalty", crimes that do not result in the death or wounding of another might incur capital punishment such as nonviolent offenses include arms trading, cowardice as a member of Pakistan's army and fabricating or giving false evidence to procure the conviction of capital offence, these offense are not punishable by death in international law. ${ }^{1}$ Pakistan has two parallel systems with unequal sentencing trends. In Pakistan many wrongful convictions are eventually reversed in appellate courts, but innocent individuals have faced torturous death cell conditions for decades. ${ }^{2}$ Thousands of Pakistanis have lost years of their lives, their families in complete ruin having had to bear the legal fees, trauma and social stigma of their incarcerations. In October last year, the Supreme Court had acquitted two brothers in Bahawalpur after they spent 11 years on death row, only to find they had already been executed the year before. ${ }^{3}$

Another prisoner was found innocent a year after he had been found dead in his cell. There are many more cases like this, considering a condemned prisoner will spend an average of 11 years on death row, the Justice Project fears. ${ }^{4}$

"Pakistan's troubling and continued use of the death penalty has continuously fallen short of meeting its international human rights commitments and fair trial standards, as well as our own domestic laws," says Sarah Belal, executive director of the Justice Project. "The death penalty is not an effective tool to curb militancy and crime, as the data clearly shows, yet has been increasingly used for political gain. ${ }^{5}$

\subsection{The Real Evil behind Terrorism and Homicides}

Corruption, low economic growth, unequal distribution of wealth, unemployment, high inflation rate and unaffordable health facilities make the life harder in Pakistan for a common person ${ }^{6}$. The analysis of Figure 5 indicates a significant relationship between terrorists' causalities, homicides and economic growth.

\footnotetext{
${ }^{1}$ See Qazis'Verdict Can't be challenged in SC, NEWS, Apr. 16, 2009, http://thenews. jang.com.pk/top_story_detail.asp?Id=21541. But see Akhtar Amin, Qazi Courts to Work Under High Court: NWFP AG, DAILY TIMES, Apr. 22, 2009, http://www.dailytimes.com.pk/default.asp?page= 2009\04\22 \story_22-4-2009_pg7_1. See also PAK. CONST. (1973) art. 175. See generally ALMAWARDI, THE ORDINANCES OF GOVERNMENT (Wafaa H. Wahba trans., 2006); IBN TAIMIYYA, ON PUBLIC AND PRIVATE LAW 11-35 (Omar A. Farrukh trans., 1966

${ }^{2}$ Dawn news Daniyal Yousaf October 04, 2018.

${ }^{3}$ Dawn.com Updated July 06, 2017.

4 ibid

5 Human Rights Common of Pakistan, State of Human Rights in 2014, p. 94, http://hrcpweb. org/hrcpweb/data/HRCP\%20Annual\%20Report\%202014\%20-\%20English.pdf, 2015.

6 Human Rights Common of Pakistan, Slow March to the Gallows: Death Penalty in Pakistan, p. 55 www.fidh.org/IMG/pdf/Pakistan464angconjointpdm.pdf, Jan. 2007.
} 


\section{Inverse Growth among Terrorism, Homicide and GDP Per Capita}

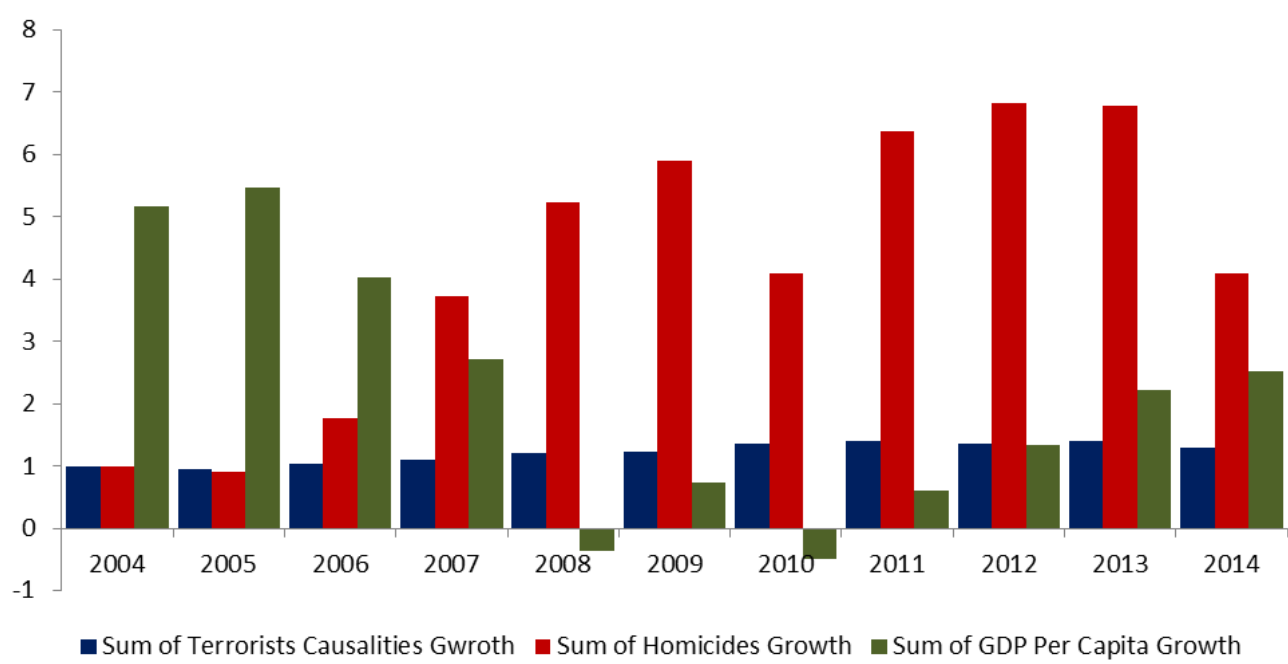

Figure 5: Inverse Relationship between Terrorism, Homicide and Economic Growth (Author generated; Data Source: Dawn.com 5 Oct, 2018)

It is clear from Figure 5, when economic growth is high the growth rate of terrorists causalities and homicides are low vice versa the low economic growth rate have inverse impact on the homicide and terrorists causalities. Similarly high political instability also leads to high terrorists activities in Pakistan. There is also strong positive correlation between terrorist causalities and homicides, shown in Figure 6. In Pakistan people kills each other for personal garages and personal motives like profit or revenge. The relationship between terrorist's causalities and homicide in Pakistan also raise the question that may be some of the homicides are named terrorists causalities under the cover of terrorism or vice versa.

\section{Correlation between Terrorist's Causalities \& Homicides}

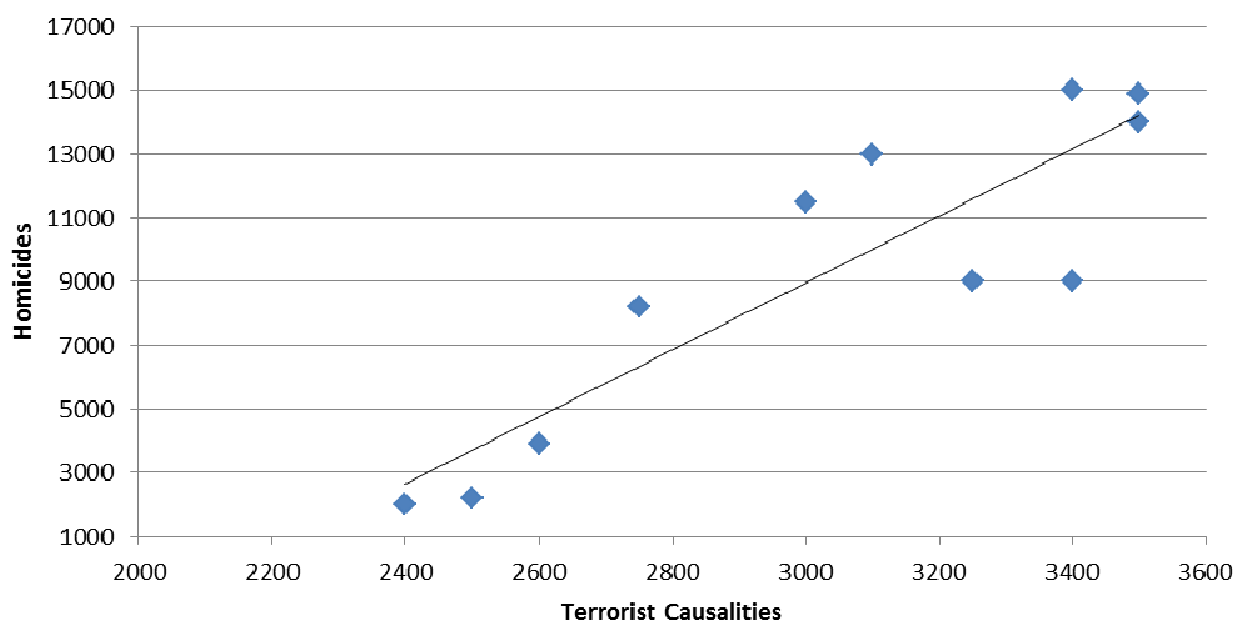

Figure 6: Correlation between Terrorist Causalities and Homicides (Author generated; Data Source: Dawn.com 5 Oct, 2018)

To sum up from Figure 4 and 5, the real evil in Pakistani society is the worse economic condition which leads to crimes like murdered, high robberies, kidnaping and terrorist activities; to show high performance police arrest innocent people like Aftab Bahadur, and the court declare him as a terrorists and hanged. Similarly, hundreds of innocent people are in prison in charges of terrorists' activities and police forcefully confessed from them.

A closer look at yearly trends of executions shows that Anti-Terrorism Courts (ATC) accounted for only 
$16 \mathrm{pc}$ of executions, the Justice Project says. In 2015, 65 people tried by ATCs were hanged, but that figure dropped to eight from Jan 2016 to May 2017. The majority of death sentences have been carried out by district and sessions courts, which do not have jurisdiction over terrorism cases, Figure 6 show the executions taken place by type of courts. ${ }^{1}$

Further, data indicates that the government is mostly hanging terrorists through military courts in Khyber Pakhtunkhwa and through ATCs in Sindh, according to the Justice Project. Another trend that has emerged is that the number of executions spike in the wake of a terrorist attack, especially in Punjab. This indicates that the use of executions, like the lifting of the moratorium, is often a reactionary step, according to the researchers ${ }^{2}$.

In Punjab, there is another worrying trend that indicates that executions are being used as a means to make room in prisons that are facing overcrowding. Currently, 25 of the 27 prisons in the province house more prisoners than their capacity and the highest number of executions take place in the most overcrowded prisons.

\section{Execution by Court Type}

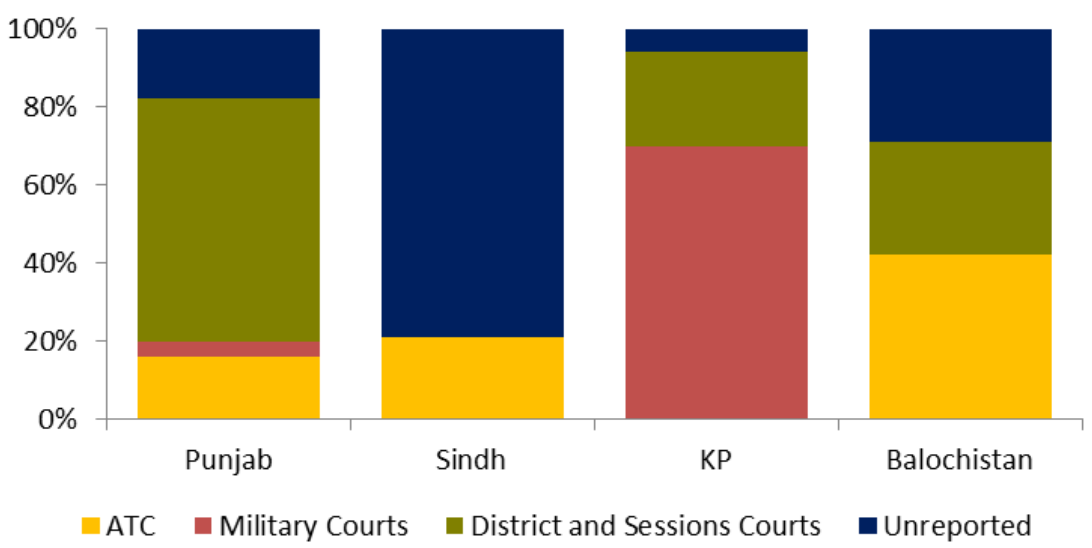

Figure 6: The Execution taken Place by Court Types (Author generated; Data Source: Justice Project Report 2017)

\subsection{Actual Convictions for Terrorist Offences among those Tried as Terrorists}

According to the Justice Project Pakistan $2014^{3}$, more than one in ten of the prisoners on death row were tried as terrorists in Pakistan; moreover $40 \%$ of the prisoners tried on death row tried as terrorists belong to Sindh province. In addition, table 1 provide the information about the prisoners who were tried as terrorists in antiterrorists courts either found involved in terrorists activities or not but were subjected to death sentence. The table 1 indicates a great concern that more than a quarter of the prisoners who were tried as terrorists in antiterrorism courts were not convicted of a terrorist offence under the ATA. In many instances, these death row prisoners remain wrongly marked as 'terrorists' in prison and court records - potentially now placing them at an unjustifiably elevated risk of execution. According to the projected statistic $90 \%$ of the prisoners those who were sentenced death penalty as a terrorist were not actually guilty of any terrorist's offence.

\footnotetext{
${ }^{1}$ Intl. Crisis Group, Reforming Pakistan's Criminal Justice System, pp. 1-4, Asia Report No. 196, Dec. 6, 2010. Sikander Ahmed Shah, Cheema Moeen, \& Waleed Khalid, Police Order 2002: Police Reforms in Pakistan, p. 221, in Devolution and Governance: Reforms in Pakistan, Oxford University Press Pakistan, 1st ed., Mar. 27, 2008.

${ }_{2}^{1}$ Justice Project Pakistan \& Reprieve, Terror on Death Row, p. 17, www.reprieve.org.uk/wp
Justice Project Pakistan \& R Reprieve, Terror on Death Row, p. 17, www.reprieve.org.uk/wp content/uploads/2016/12/2016_12_18_PUBPakistan- Terror-Courts-Report-JPP-and-Reprieve.pdf, Dec. 2016.

${ }^{3}$ Please see Terror on death row, the abuse and overuse of Pakistan's anti-terrorism legislation. A report by Justice Project Pakistan and Reprieve, December 2014. Website https://reprieve.org.uk/wp-content/uploads/2014/12/2014_12_18_PUB-Pakistan-Terror-Courts-ReportJPP-and-Reprieve.pdf last accessed December 19, 2018.
} 
IIIII

Province
\begin{tabular}{|l|l|l|l|}
\hline & $\begin{array}{l}\text { Pentence to death for a } \\
\text { terrorist offence under the } \\
\text { ATA }(\% \text { of total) }\end{array}$ & $\begin{array}{l}\text { Not convicted of any offence under } \\
\text { the ATA- sentenced to death under } \\
\text { non-terror provisions } \% \text { of total) }\end{array}$ & $\begin{array}{l}\text { Projected percentage who } \\
\text { are not terrorists } \\
\text { sentenced to death }\end{array}$ \\
\hline baluchistan & $21(80.77 \%)$ & $5(19.23 \%)$ & $22(84.62 \%)$ \\
\hline KPK & $14(70.00 \%)$ & $6(30.00 \%)$ & $17(85.99 \%)$ \\
\hline Punjab & $430(67.05 \%)$ & $211(32.92 \%)$ & $555(86.58 \%)$ \\
\hline Sindh & $97(74.05 \%)$ & $34(25.95 \%)$ & $112(85.50 \%)$ \\
\hline Total & $562(68.70 \%)$ & $256(31.29 \%)$ & $706(86.31 \%)$ \\
\hline
\end{tabular}

Table 1: Prisoners Tried in Anti-Terrorism Courts and sentenced for Death (Data Source: Pakistan Justice Report 2014)

\section{Case Study: A Death Row Prisoner Shafqat Hussain finally Executed}

Shafaqat Hussain had been arrested for abduction of a seven year old boy, Umair, who lived in the same building where Shafqat worked as a night gatekeeper in Noor Square, Karachi. On May 21st, 2004, Shafaqat Hussain was forced to stand inside a Karachi jail cell and urinate on a mesh of live wire. The area is a slum in Orangi Town, high crime vicinity with regular instances of kidnappings and targeted killings. For five days, he was subjected to torture by suspension, electrocution, beatings and sleep deprivation, until he confessed to Umair's abduction and murder before a magistrate in Anti-Terrorism Court. According to witness accounts, all the men taken into custody were violently beaten in separate localities to extract confessions for Umair's abduction. The others were eventually released, allegedly by paying bribe money equal to the sum of at least Rs. 80,000. Shafqat Hussain states in a transcript seen by The Nation (news agency), that the police said he would be released if he could produce a required sum of money.

"They told me about Umair's murder and told me to give them money and then they would let me go and find someone else to charge with the crime. But I did not have any money to give them." According to Shafqat's lawyer, and director of Justice Project Pakistan, Sarah Belal, "It is widely recognized and acknowledged that torture by the police in Pakistan is systemic and indeed widespread. The fact that there is credible evidence relating to Shafqat's confession being obtained though torture is a surprise to no one. The Pakistani government is obligated under CAT to hold an inquiry into the claims of torture in Shafqats case. It will be a travesty of justice to execute him without holding that inquiry and indeed a violation of Pakistan's international obligations." Shafqat alleges he was tortured for several days in police custody by the following means, suspension by means of a pole passed between ties, securing his hands and feet; compression of and traction on his wrists by vertical suspension from handcuffs applied to his wrists; falaka (beating on the soles of the feet with a blunt instrument); burning, by application of lit cigarettes to the arm; blindfolding and sleep deprivation; forcefully being made to drink water and urinate on live wires to cause electrocution. After eleven years in jail and two last minute reprieves, Shafqat has been set to hang at $4.30 \mathrm{am}$ on Tuesday, the 9th of June 2015. His juvenility at the time of his alleged offence is disputed, and has become the cause of a worldwide campaign to halt his execution. Human rights lawyers working on Shafqat's case contend that he was under the age of 18, and legally a juvenile at the time of Umair's abduction. Furthermore, there is overwhelming evidence to suggest that his confession, which is the sole piece of evidence against him, was induced after days of torture. According to one security official, "In those days, he's lucky they didn't kill him". ${ }^{1}$ Alas Shafqat was hanged at the mentioned date, it is a black spot on the judicial system, but unfortunately no actions have been taken till yet to stop these innocent convictions or one may be able to say innocent murder or innocent killing.

\section{Conclusion}

Present study's facts and figures reveal that, how different risk factors play out in capital prosecutions, no criminal justice system is free of error, regardless of the system, region, or political regime and any state that applies the death penalty will inevitably sentence innocent people to an irreversible punishment. Further, Pakistan's justice system is ridden with deficiencies and abuses of authority. Police routinely coerce defendants into confessing, often by torture, and courts admit and rely upon such evidence. Poor defendants must rely on attorneys who typically provide only cursory and ineffective representation.

Moreover study investigated that there are also huge gaps and incompetence's of investigation system in Pakistan such as lack of modern investigation methods, falsification of evidence, inadequate resources, corrupt practices and use of torture and brutality by investigation agencies for obtaining false confession from the defendant. Meanwhile, there are huge flaws in the judicial system such as inadequate resources, corruption,

1 For more details please visit; https://nation.com.pk/08-Jun-2015/shafqat-hussain-the-case-for-innocence See also http://dunyanews.tv/en/Pakistan/274324-Shafqat-Hussain-age-case-IHC-directs-PM-Presiden See also,

https://www.presstv.com/Detail/2015/08/04/423206/Pakistan-execution-teenager-abduction-murder-Shafqat-Hussain-Karachi 
inadequate criminal defense, lack of judicial independence and most dangerous are outdated and unclearly define laws such as Anti-Terrorism Act which are vague and do not provide sufficient guidance. All these gaps in investigation and judicial system lead to the wrongful executions of innocent people in Pakistan. In addition, the bad socio-economic conditions, unequal wealth distribution, health inequalities and most dangerous justice inequalities are the main evils behind terrorism activities in Pakistan and the root cause of the mentioned are highly level of corruption at institutional and individual levels.

A closer analysis of ATA prosecutions reveals the overreach of anti-terrorist laws in Pakistan and the overuse of the death penalty in particular. JPP statistics indicate that in 2014, more than 800 alleged "terrorists" were on death row due to ATA prosecutions; of these, 256 had no pretense of a link with terrorism. Of the remaining 562 cases, JPP concluded that only 20 percent of those sentenced to death under the ATA were genuinely "terrorists" as the word is commonly understood - that is, motivated by a broader political or religious ideology that distinguishes the offense from normal criminal or personal motives like profit or revenge. The charging of Shafqat Hussain exemplifies this problem. At the age of 14, Shafqat was accused of kidnapping, a crime normally heard in ordinary criminal courts under Pakistan's Penal Code. However, because the charge was deemed to have "created a sense of terror in the wider community," he was tried in an anti-terrorism court, dramatically altering the trajectory of his case. As a minor, Shafqat should never have been sentenced to death. Further, the prosecution relied almost exclusively on a confession obtained via torture. Speaking in the National Assembly, Minister of Interior Chaudhry Nisar Ali Khan admitted that the case was in reality "not connected to terrorism" at all and had more appropriately "concerned civil society." Even so, Shafqat was ultimately executed for his sentence under the ATA.

It is revealing figure that Pakistan's death row contains an alarming number of innocent individuals, juveniles, the physically and mentally ill and others who have been convicted of crimes that should not attract the death penalty, many of whom have been subjected to torture and extreme brutality. Today, Pakistan continues to sentence to death persons who are juveniles, mentally ill, or very likely innocent under the AntiTerrorism Act. It is obvious from the literature and statistical illustration that ATA has been misused or overused in Pakistan in the cases which could be better and more appropriately tried in ordinary courts. In additions, in maximum cases police has falsified the evidences or obtained a forced confession from the victim by use of excessive use of torture and brutality. Furthermore, it is evident from the statistics that police; government official and even judiciary is involved in corruption practices in Pakistan which has high correlation with the wrongful convictions. ATA creates a criminal system in which there is no guarantee that justice will be granted as it is full of flaws as discussed in literature.

The systemic violations illustrated in this study compel the conclusion that Pakistan's continuing practice of capital punishment violates international law. The irreversible nature of execution mandates the immediate reinstatement of the moratorium on all executions. Yet a moratorium alone will not suffice. In the light of literature and statistical analysis the present author would recommend that:

1. The death sentence awarded by anti-terrorism or military courts should be reviewed by ordinary courts and the defendant should be given a fair trial.

2. The current anti-terrorism legislation should be suspended and till a full review. There should be a detail review of all those provisions which curtail the safeguards of fundamental freedom.

3. Reform the Evidence Act to shift focus from witness testimony to modern scientific evidence; and invest in strong state-protection programs for witnesses, investigators, prosecutors and judges in terrorism and other major criminal cases. Police must be made accountable for their evil deeds.

4. Section 21-H of the ATA (permitting extrajudicial confessions) should be immediately repealed.

5. Adoption of legislative and administrative measures to ensure that all legal proceedings are conducted in accordance with Article 14 ICCPR.

6. Strict measure for corruption control and money laundering, as this is the mother of terror financing in Pakistan. 